Migration, Householding and the Well-being of Left-behind Women in Rural Ningxia Author(s): Tamara Jacka

Source: The China Journal, No. 67 (January 2012), pp. 1-22

Published by: The University of Chicago Press on behalf of the College of Asia and the Pacific, The Australian National University

Stable URL: http://www.jstor.org/stable/10.1086/665737

Accessed: 24-01-2018 23:57 UTC

JSTOR is a not-for-profit service that helps scholars, researchers, and students discover, use, and build upon a wide range of content in a trusted digital archive. We use information technology and tools to increase productivity and facilitate new forms of scholarship. For more information about JSTOR, please contact support@jstor.org.

Your use of the JSTOR archive indicates your acceptance of the Terms \& Conditions of Use, available at http://about.jstor.org/terms

College of Asia and the Pacific, The Australian National University, The University of Chicago Press are collaborating with JSTOR to digitize, preserve and extend access to The China Journal 


\section{MIGRATION, HOUSEHOLDING AND THE WELL-BEING OF LEFT-BEHIND WOMEN IN RURAL NINGXIA}

\section{Tamara Jacka*}

In recent years, large-scale labor migration has had a significant impact on the social landscape of rural China. Large numbers of rural Chinese men work away from home for long periods until they reach late middle age, while rural women also often migrate when young, but generally return to the countryside to get married. ${ }^{1}$ After marriage and childbirth, most women remain in the village, but repeated episodes of migration are increasingly common among married women in their $20 \mathrm{~s}$ and $30 \mathrm{~s}^{2}$ Consequently, much of the Chinese countryside is dominated by split households and a depleted, shifting population of middle-aged women, children and the elderly.

The starting point for this paper is a new body of research that has emerged in China since the mid-2000s, which expresses concern about the impact of rural outmigration on the well-being of the so-called “left-behind” (liushou 留守) population, specifically, “left-behind women” (liushou funü 留守妇女). ${ }^{3}$ These recently published

* This paper draws on research funded by an Australian Research Council Grant (DP0985775). I am grateful to my Chinese research partners and assistants for their help in conducting fieldwork, and to the women who participated in the research. An earlier version of this paper was presented to a workshop on Householding in Transition: Emerging Dynamics in "Developing" East and Southeast Asia, in Singapore, July 2011, and I thank Mike Douglass, Cindy Fan, Liu Jieyu and other workshop participants for their stimulating discussion. I also thank anonymous referees as well as Sally Sargeson, Jonathan Unger and Andrew Kipnis for their valuable feedback.

1 Cindy Fan, China on the Move: Migration, the State and the Household (London: Routledge, 2008), pp. 86-88.

2 Among both men and women, migration rates peak at the 20-24 age group and decline thereafter. Overall, however, migrant women tend to be younger than migrant men and, after the age of about 30, female migration rates decline much more rapidly than male rates (Cindy Fan, China on the Move, pp. 76-78).

3 A note about terminology: first, the English term "left-behind" has connotations of abandonment, which, as I suggest in this paper, are problematic. These connotations are not as strong in the Chinese word, liushou, which can be translated more literally as "(those who) stay and hold the fort" (Xiang Biao, "How Far are the Left-behind Left Behind? A Preliminary Study in Rural China", Population, Space and Place, Vol. 13 (2007), p. 181. Nevertheless, the sense that the liushou population has been abandoned in the rural hinterland pervades the Chinese literature. In this paper, I continue to use the term "left-behind" simply because it is 
studies are important, for, although rural migration, especially rural-to-urban migration, has been attracting widespread attention from observers within and outside China for more than 20 years, most of that attention has been directed toward the significance of migration for national development, its impact on urban communities, and the experiences of migrants themselves. ${ }^{4}$ The new studies represent the first sustained effort on the part of Chinese scholars to understand the social consequences of migration for rural communities of origin, and the situation of those who remain in the countryside. ${ }^{5}$

In this paper, however, I argue that the scholarly contribution which these studies make is limited by a lack of appreciation of the embeddedness of migration patterns and left-behind people's responses to them in rural "householding": that is, the strategies and processes through which rural households create and reproduce themselves. The term "householding" has been used by Mike Douglass to highlight the understanding that "creating and sustaining a household is an ongoing, dynamic social process that covers all lifecycle stages and extends beyond the family". "As a basic unit of social reproduction", he writes, citing Nancy Folbre, "the household is a principal locus of social relations not only for the physical reproduction of human life

the most common translation for liushou, and the most commonly used term in the global migration literature (see, for example, Mika Toyota, Brenda S. A. Yeoh and Liem Nguyen, "Editorial Introduction: Bringing the 'Left Behind' Back into View in Asia: A Framework for Understanding the 'Migration-Left Behind Nexus"', Population, Space and Place, Vol. 13 (2007), pp. 157-61.

Second, in this paper, I use the term "well-being" in a very loose sense. The Chinese word for well-being or welfare, fuzhi, common in Hong Kong and Taiwan, is rare in mainland China, and does not appear in the studies under consideration. Instead, these refer variously to physical and mental health (shenxin jiankang); psychology and emotions (xinli ganshou); life satisfaction (shenghuo manyidu); quality of life (shenghuo zhiliang); pressures and worries (yali danxin); family and marital relations (jiating guanxi, hunyin guanxi); and loads and burdens (fudan), including workloads and psychological burdens.

4 See, for example, Dorothy Solinger, Contesting Citizenship in Urban China: Peasants, Migrants, the State, and the Logic of the Market (Berkeley: University of California Press, 1999); Cindy Fan, China on the Move; Tamara Jacka, Rural Women in Urban China: Gender, Migration and Social Change (Armonk: M. E. Sharpe, 2006).

5 The object of discussion in this paper is a body of Chinese research focused explicitly on the situation of "left-behind women"; see below for examples. To date, there have been only a handful of English-language studies examining the situation of rural Chinese women whose family members have migrated out; see, however, Rachel Murphy, "The Impact of Labor Migration on the Well-Being and Agency of Rural Chinese Women: Cultural and Economic Contexts and the Life Course", in Arianne M. Gaetano and Tamara Jacka (eds), On the Move: Women and Rural-to-Urban Migration in Contemporary China (New York: Columbia University Press, 2004), pp. 243-76; Ren Mu and Dominique van de Valle, Left Behind to Farm? Women's Labour Re-allocation in Rural China, Policy Research Working paper WPS5107, The World Bank Development Research Group, Human Development and Public Services Team (2009), available at http://elibrary.worldbank.org/ content/workingpaper/10.1596/1813-9450-5107, accessed 16 April 2011.

6 Mike Douglass, "Global Householding in Pacific Asia", International Development Planning Review, Vol. 28, No. 4 (2006), p. 423. 
but also for the material and psychological well-being and sociocultural mores of its members". 7 Douglass has been particularly interested in the interconnections between international migration and "global householding" and, specifically, the extent to which householding in the Philippines and other parts of Asia is increasingly reliant on movements and interactions between people across national borders. ${ }^{8}$

This study differs from that by Douglass in focusing on internal rather than international migration. However, I am not the first to emphasize that movements and connections are a crucial part of rural life within China. Most recently, for example, Shannon May has written of young peoples' rural-urban migration as a "gendered strategy through which parents seek to weave a web of social security through extended family relationships while remaining in the countryside". ${ }^{9}$ From a different perspective, Jan Douwe van der Ploeg and Ye Jingzhong argue that contemporary patterns of rural-urban migration should be seen as an extension of households' multiple job-holding practices, which have long been a "constant, albeit highly differentiated, feature of rural life in China". ${ }^{10}$

In this paper, I contribute to this literature by arguing for the utility of Douglass' conceptualization of migration and householding. Douglass' model is a useful way of drawing together the links that others observe between migration and other aspects of rural life, and of understanding the impact of outmigration on the left-behind in relation to broader social and economic relations in the countryside. Employing this model helps to bridge divides between studies of transnational and intra-national mobility and ties and, within Chinese studies, between research on migration and rural society.

I draw on findings from fieldwork conducted recently in Snow Valley (a pseudonym), a poor rural county in the southern part of Ningxia Hui Autonomous Region. Colleagues and I conducted fieldwork in seven villages across two townships. Although there is a large Hui population in Ningxia, Snow Valley is overwhelmingly a Han county, and each of the villages that we visited included no more than one or two Hui households. Across the two townships, the proportion of households with at least one migrant ranged from 40 to 90 per cent.

7 Nancy Folbre, "Hearts and Spades: Paradigms of Household Economics", World Development, Vol. 14, No. 2 (February 1986), pp. 245-55, cited in Mike Douglass, "Global Householding in Pacific Asia", p. 423.

8 Mike Douglass, "Global Householding in Pacific Asia"; idem., "The Globalization of Householding and Social Reproduction in Pacific Asia", Philippine Studies, Vol. 55, No. 2 (2007), pp. 157-81.

9 Shannon May, "Bridging Divides and Breaking Homes: Young Women's Lifecycle Labour Mobility as a Family Managerial Strategy", The China Quarterly, No. 204 (December 2010), p. 900. See also Ellen R. Judd, "Family Strategies: Fluidities of Gender, Community and Mobility in Rural West China", The China Quarterly, No. 204 (December 2010), pp. 921-38.

10 Jan Douwe van der Ploeg and Ye Jingzhong, "Multiple Job Holding in Rural Villages and the Chinese Road to Development", Journal of Peasant Studies, Vol. 37, No. 3 (2010), p. 515. 
The first part of the paper outlines the findings of previous survey studies on the well-being of left-behind women, and compares these with data obtained from a questionnaire-based survey that we conducted in Snow Valley in July 2010. The second part of the paper considers the well-being of left-behind women from a different perspective. Drawing on semi-structured interviews undertaken in Snow Valley in 2010 and 2011, I present a story of one rural woman and her family, and discuss the ways in which the case study illustrates the interconnections between rural migration, other aspects of householding, and the well-being of rural women. My concluding remarks focus on the value of the concept of householding as a more analytically fruitful way of framing research on left-behind women than the approaches heretofore adopted.

\section{Survey Findings}

Chinese survey studies of "left-behind women" usually define the term to include married women aged 18 to 60 years old whose husbands have migrated out and have spent 6 months or more of the preceding year away from home. ${ }^{11}$ The vast majority argue that outmigration, while improving household income, has a negative impact on the well-being of left-behind women. They claim that such women have particularly heavy workloads, are under high levels of stress and suffer poor mental and physical health $;^{12}$ they suffer feelings of loneliness and insecurity; ${ }^{13}$ and their relations with their husbands are relatively unsatisfying, conflicted and unstable. ${ }^{14}$

11 However, some studies use the term "left-behind women" to refer only to married women aged 55 or under. See, for example, Li Xirong, "Nongcun liushou funü de hunyin wendingxing tanxi: yudong HCcun de ge an yanjiu" (The Stability of Marriages Among Rural Left-behind Women: A Case Study of HC Village in East Henan), Funü yanjiu luncong (Collection of Women's Studies), Vol. 6, No. 89 (2008), pp. 26-29. Older women whose husbands or adult children have migrated are generally not referred to as "left-behind women" but, instead, as part of the "left-behind elderly" (liushou laoren) population.

12 See, for example, Xu Chuanxin, "Nongcun liushou funü yanjiu: huigu yu qianzhan" (Studies on Left-behind Women in Rural Areas: Review and Prospects), Renkou yu fazhan (Population and Development), Vol. 15, No. 6 (2009), pp. 55-56; Xu Chuanxin, "Xibu nongcun liushou funü jiating yali ji yingxiang yisu fenxi" (An Analysis of Family Stress and Factors Influencing It Amongst Left-behind Women in Western Rural Areas), Renkou yu jingji (Population and Economics), Vol. 178, No. 1 (2010), pp. 73-78; Wu Huifang and Ye Jingzhong, "Zhangfu waichu wugong dui nongcun liushou funü de xinli yingxiang fenxi" (Analysis of the Psychological Impact of Husbands' Migration on the Women Left at Home in Rural China), Zhejiang Daxue xuebao (Renwen shehui kexue ban) (Journal of Zhejiang University [Humanities and Social Sciences]), Vol. 1 (2010), pp. 13-14.

13 See, for example, Xu Chuanxin, "Nongcun liushou funü yanjiu: huigu yu qianzhan", pp. 55-56; Wu Huifang and Ye Jingzhong, "Zhangfu waichu wugong dui nongcun liushou funü de xinli yingxiang fenxi”, pp. 14-18.

14 See, for example, Lou Binbin, "Zhangfu waichu dui funü de yingxiang" (The Impact of Husband Migration on Women) in Zheng Zhenzhen and Xie Zhenming (eds), Renkou liudong yu nongcun funü fazhan (Migration and Rural Women's Development) (Beijing: Shehui Kexue Wenxian Chubanshe, 2004), pp. 114-28; Li Xirong, "Nongcun liushou funü 
Curiously, however, the survey data presented in these studies do not provide strong support for their claims. Some studies present data only on left-behind women, so it is not possible to determine whether or not their situation is significantly different from that of women whose husbands were away from home for less than six months in the preceding year. Other studies, which do present comparative data on the two groups, vary somewhat in their findings, but, in general, report only small differences in well-being between them. As Xiang Biao notes in his preliminary Englishlanguage review of the Chinese literature, "all three left-behind groups, namely wives, the elderly and children, do encounter various problems, but existing comparative studies show that in general their situation is not much worse than that of those living with other family members in the same community". ${ }^{15}$

The data obtained from the questionnaire survey which we conducted in Snow Valley similarly indicate only very small differences between the well-being of left-behind and non-left-behind women. This questionnaire survey was carried out with a total of about 2,000 women. ${ }^{16}$ In each of the seven villages that we visited, our sample included all women aged between 16 and 80 years who were present and had been living in the village for the past six months. However, the data that I present here is limited to the married respondents aged $21-60 .{ }^{17}$ These numbered 1577, of whom 441 were left-behind women. About 95 per cent of the left-behind women were aged between 21 and 50. In these age cohorts, they comprised 34 per cent of all respondents. The lack of left-behind women aged 51-60 can be explained by the fact that few men of this age are still physically fit enough to undertake the heavy manual labor characteristic of most migrant work.

Among the left-behind women aged 21-60, the median household income reported for the preceding twelve months $(6,000$ yuan) was higher than that of women with non-migrant husbands (5,000 yuan). ${ }^{18}$ However, when asked questions about

de hunyin wendingxing tanxi"; Xu Chuanxin, "Nongcun liushou funü yanjiu: huigu yu qianzhan", p. 56; Xu Chuanxin, "Hunyin guanxi manyidu: liushou funü yu feiliushou funü de bijiao yanjiu" (Marital Satisfaction: A Comparative Study of Left-behind and Non-leftbehind Women), Funü yanjiu luncong, Vol. 5, No. 95 (2009), pp. 25-32.

15 Xiang Biao, "How Far are the Left-Behind Left Behind?", p. 180.

16 The questionnaire was conducted in July 2010, by a team of interviewers from the Snow Valley Public Health Bureau, trained and supervised by my collaborative research partner, who wishes to remain anonymous. The research partner was also responsible for subsequent SPSS data input and analysis. The two townships in which the survey was conducted were selected to provide a contrast between villages with high rates of migration and those with lower rates of migration. Within each township, villages closest to the township centre were selected and every woman in each village surveyed until we reached our target of about 1000 women in each township.

17 Respondents aged 16-20 are not included because there were only 4 in this cohort. The exclusion of women over the age of 60 is in line with the most common definition of "leftbehind women", as explained above.

18 The average household size among respondents was 5 people. Thus, the average annual per capita income was 1,200 yuan among the households of left-behind women and 1,000 yuan among the households of women with non-migrant husbands. In comparison, the official 
workloads, worries, life satisfaction and health, left-behind women and those with nonmigrant husbands gave very similar responses. As illustrated in Tables $1-4$, there were some variations in these aspects of well-being between respondents of different ages. However, within each age cohort, there was no statistically significant difference in well-being between left-behind women and those with non-migrant husbands.

One aspect of well-being in which we did find small differences between leftbehind and those with non-migrant husbands relates to intra-household conflict. ${ }^{19}$ Unsurprisingly, across the 21-60-year age range, significantly fewer left-behind respondents (38.1 per cent) said that they had had conflicts with their husband in the previous 12 months than did those whose husbands had been at home most of the year $(45$ per cent $)(p<0.05)$. However, with respect to conflict with other family members, across the 21-60-year age range there was no statistically significant difference between the two groups. More surprisingly, women in the youngest cohort (21-35 years) bucked the general trend with respect to conflict both with husbands and with other family members. Thus, this is the only cohort in which we found no significant difference between left-behind women and those with nonmigrant husbands with respect to spousal conflict. In contrast, this is the only cohort in which we found a significant difference between the two groups of women with respect to conflict with other family members. In this youngest cohort, significantly fewer left-behind women (16.6 per cent) reported conflict with other family members than did women with non-migrant husbands $(27.1$ per cent $)(p<0.05)$.

\section{Table 1: Workloads}

"In the last month, how many hours per day did you spend in..." (composite of responses to 10 questions about different kinds of paid and unpaid work)

\begin{tabular}{|l|l|l|l|}
\hline Age (Yrs) & $\begin{array}{l}\text { No. of months } \\
\text { husband was away } \\
\text { in last year }\end{array}$ & $\begin{array}{l}\text { N } \\
\text { (married women) }\end{array}$ & $\begin{array}{l}\text { Work Hours per } \\
\text { Day } \\
\text { (Mean } \pm \text { Standard } \\
\text { Deviation) }\end{array}$ \\
\hline \multirow{2}{*}{$21-35$} & $0-5$ & 214 & $9.98 \pm 3.03$ \\
\hline \multirow{2}{*}{$36-50$} & $6-12$ & 144 & $9.80 \pm 2.52$ \\
\hline \multirow{2}{*}{$51-60$} & $0-5$ & 606 & $9.20 \pm 2.60$ \\
\cline { 2 - 4 } & $6-12$ & 273 & $8.88 \pm 2.30$ \\
\cline { 2 - 4 } & $0-5$ & 316 & $8.23 \pm 2.92$ \\
\hline
\end{tabular}

national average annual rural cash income per person at that time was 6,270 yuan (National Population and Family Planning Commission of China, "Basic Conditions of Rural Households, 1990, 1995, 2000, 2008, 2009”, http://www.npfpc.gov.cn/en/about/ detail.aspx?articleid=101222123614579955, (2010), accessed 8 April 2011.

19 Survey respondents were asked the following questions: "In the past year, have you had many conflicts (including verbal or psychological conflict and physical conflict) with your husband?" and "In the past year, have you had many conflicts (including verbal or psychological conflict and physical conflict) with other family members?" In both cases, possible responses were "none", "very few", "few", "many" or "very many". Here, we report the proportions of women who gave any response other than "none". 


\section{Table 2: Worries}

"In the last year, have you felt any pressure or worry about the following, and if so, how much? You can answer 'none at all' (1); 'a little' (2); 'it's hard to say' (3); 'rather a lot' (4); or 'extremely high level' (5)..." (composite of responses to 14 questions)

\begin{tabular}{|l|l|l|l|}
\hline Age (Yrs) & $\begin{array}{l}\text { No. of months } \\
\text { husband was away } \\
\text { in last year }\end{array}$ & $\begin{array}{l}\text { N } \\
\text { (married women) }\end{array}$ & $\begin{array}{l}\text { Level of Worry } \\
\text { (Mean } \pm \text { Standard } \\
\text { Deviation) (14=no } \\
\text { worries; } \\
\mathbf{7 0 = e x t r e m e l y ~ h i g h ~} \\
\text { level of worry) }\end{array}$ \\
\hline \multirow{2}{*}{$21-35$} & $0-5$ & 214 & $21.57 \pm 6.42$ \\
\cline { 2 - 4 } & $6-12$ & 144 & $23.54 \pm 6.01$ \\
\hline \multirow{2}{*}{$36-50$} & $0-5$ & 604 & $23.61 \pm 6.72$ \\
\cline { 2 - 4 } & $6-12$ & 272 & $23.80 \pm 5.85$ \\
\hline \multirow{2}{*}{$51-60$} & $0-5$ & 315 & $22.21 \pm 6.25$ \\
\cline { 2 - 4 } & $6-12$ & 22 & $23.95 \pm 6.88$ \\
\hline
\end{tabular}

\section{Table 3: Life Satisfaction}

"I'd like to ask about your level of satisfaction with several aspects of life." Possible responses: extremely satisfied (1); satisfied (2); neither satisfied nor dissatisfied (3); dissatisfied (4); extremely dissatisfied (5) (composite of responses to 10 questions)

\begin{tabular}{|l|l|l|l|}
\hline Age (Yrs) & $\begin{array}{l}\text { No. of months } \\
\text { husband was away } \\
\text { in last year }\end{array}$ & $\begin{array}{l}\text { N } \\
\text { (married women) }\end{array}$ & $\begin{array}{l}\text { Level of Satisfaction } \\
\text { (Mean } \pm \text { Standard } \\
\text { Deviation) } \\
\text { (10=extremely } \\
\text { satisfied; } \\
\mathbf{5 0 = e x t r e m e l y ~} \\
\text { dissatisfied) }\end{array}$ \\
\hline \multirow{2}{*}{$21-35$} & $0-5$ & 213 & $22.62 \pm 3.96$ \\
\hline \multirow{2}{*}{$36-50$} & $6-12$ & 143 & $22.83 \pm 3.56$ \\
\hline \multirow{2}{*}{$51-60$} & $0-5$ & 606 & $22.31 \pm 3.48$ \\
\cline { 2 - 4 } & $6-12$ & 272 & $22.55 \pm 3.39$ \\
\cline { 2 - 5 } & $0-5$ & 315 & $21.45 \pm 2.69$ \\
\hline
\end{tabular}

\section{Table 4: Health}

"In the last year, how has your (physical) health been?" "In the last year, how has your psychological and mental health been?" Possible responses: Extremely good (1); good (2); average (3); poor (4); extremely poor (5) (composite of responses to two questions)

\begin{tabular}{|l|l|l|l|}
\hline Age (Yrs) & $\begin{array}{l}\text { No. of months } \\
\text { husband was away } \\
\text { in last year }\end{array}$ & $\begin{array}{l}\text { N } \\
\text { (married women) }\end{array}$ & $\begin{array}{l}\text { Health } \\
\text { (Mean } \pm \text { Standard } \\
\text { Deviation) } \\
\text { (2=extremely good; } \\
\mathbf{1 0}=\text { extremely poor) }\end{array}$ \\
\hline \multirow{2}{*}{$21-35$} & $0-5$ & 214 & $5.76 \pm 1.33$ \\
\hline \multirow{2}{*}{$36-50$} & $6-12$ & 145 & $5.11 \pm 1.44$ \\
\hline \multirow{2}{*}{$51-60$} & $0-5$ & 606 & $5.76 \pm 1.57$ \\
\cline { 2 - 4 } & $6-12$ & 273 & $5.71 \pm 1.67$ \\
\hline & $0-5$ & 316 & $6.26 \pm 1.60$ \\
\cline { 2 - 5 } & $6-12$ & 23 & $6.70 \pm 1.58$ \\
\hline
\end{tabular}


In commenting on the small differences that most studies have found between the well-being of left-behind villagers and those whose family members have not migrated out, Xiang Biao concludes that:

... the problems faced by the left-behinds cannot be solely attributed to being left behind; rather, the fundamental point is that many rural communities as a whole have been left behind economically and socially, and the communities are no longer able to provide any support for those left behind there. ${ }^{20}$

In the remainder of this paper, I present an alternative interpretation. My aim is not to refute Xiang Biao's claim that rural communities as a whole have been left behindthat is indisputably the case. However, both the survey findings on the well-being of the left-behind and Xiang Biao's explanation for them convey only a superficial, and in some respects misleading, picture of the place of migration in villagers' lives and of the difficulties faced by left-behind women and those with non-migrant husbands. Drawing on qualitative research, which attends to the interconnections between migration patterns, left-behind women's responses to others' outmigration and other aspects of householding yields a different, more complex picture.

Consider the story of one woman, whom I will refer to as $\mathrm{Li}$, and her family. This account draws on information provided by Li and her husband, mother-in-law and father-in-law, in multiple semi-structured interviews conducted with each person individually in July 2010, January 2011 and April 2011. ${ }^{21}$

\section{Li's Story}

Li is in her early thirties, married to a man whom I will call Wang. Li's family was too poor for her to go to school when she was a child, but Wang managed to get two years of senior high school education. The couple has two sons, one in primary school and the other a toddler, and they share a courtyard housing compound with Wang's parents, who are in their 60s. They live in Red Mountain, a village of 344 households located in the mountains about 2,600m above sea level, 45 minutes' drive from Snow Valley county town.

20 Xiang Biao, "How Far are the Left-Behind Left Behind?", p. 180.

21 The following account is based on two interviews which I conducted with Li in July 2010 and January 2011; an interview between a male research assistant and Li's father-in-law in January 2011; and three interviews between a female research assistant and Li's father-in-law, motherin-law and husband respectively in April 2011. Names have been changed, in order to protect identities. These interviews form part of a total of 147 semi-structured interviews, conducted by myself and two research assistants with a sub-sample of 54 left-behind and non-left-behind women from our original survey sample, most of whom we interviewed twice; household members of these women; a small number of non-related returning migrant women and men; and village leaders. Interviews were on average about an hour long, conducted individually, mostly in interviewees' homes. In most cases, the interviewer was accompanied by a member of the county Public Health Bureau, who helped to interpret between the local language and Mandarin, but there was no-one else present. Most interviews were audio-recorded with permission from interviewees. 
Wang is the second of three brothers. Fifteen years ago, he and his younger brother went to work in Xinjiang. His younger brother found work on a cattle farm in the north of Xinjiang, while Wang found a job at a vehicle repair station in Urumqi. When she married into the family, Li joined her husband, and their eldest son was born in Urumqi and went to preschool there. Meanwhile, Wang's older brother, his wife and children stayed in Red Mountain, living with his parents and working on the farm.

However, a few years ago, the older brother died in a motorbike crash, together with his young son who was riding on the back, leaving his wife a widow with two daughters in junior high school. Following this family tragedy, Wang's father recalled Wang and Li from Xinjiang so that they could take the older brother's place back at home. At about the same time, Li fell pregnant with their second child. Seeing that the older brother's wife was now without either a husband or a son, Li and Wang offered to give her this second child should it be a boy. ${ }^{22}$ As it happened, however, the widow remarried and no longer wanted Li and Wang's son after he was born, but her two daughters are still considered part of the Wang family. They have now left school and both work most of the year as waitresses in Yinchuan, the capital of Ningxia. At Spring Festival they stay with their grandparents in Red Mountain.

Since his return to Red Mountain, Wang has been going to the city of Guyuan, a few hours away, to work as a casual construction laborer, but he only spends three or four months away from home each year. He earns considerably less in Guyuan than does his brother in Xinjiang, but Li said that it is not possible for her husband to work further afield and stay away for longer, because there is too much farmwork to do at home. The Wang family has $12 \mathrm{mu}$ of farmland. ${ }^{23}$ In March and April, Wang and Li plant the potato and linseed crops, before Wang goes to work in Guyuan. He returns in July to help harvest the wheat and stays through August and September, to help to plow, plant the following year's crop of winter wheat, and harvest the potatoes. Wang and Li do most of this work by themselves, but they share the work of planting the wheat with Wang's paternal uncle and his wife, whose land is adjacent to theirs.

$\mathrm{Li}$ also raises two oxen and a pig, does most of the cooking and cleaning, and looks after the two boys. Her parents-in-law are in poor health. Her father-in-law used to help with farmwork, but stopped a couple of years ago. Her mother-in-law is not able to work in the fields, but looks after the toddler and helps to feed the animals while $\mathrm{Li}$ is in the fields. At the time of our first visit, in July, just before the

22 For another, similar example of a boy being given in adoption to a related household, see Andrew B. Kipnis, Producing Guanxi: Sentiment, Self, and Subculture in a North China Village (Durham: Duke University Press, 1997), pp. 139-40.

23 $1 m u=1 / 6$ acre. When land was first parceled out to individual households following decollectivization in 1981, the Wang family received $23 \mathrm{mu}$. There has been no redistribution of land in the village since then. This means that neither Li, nor her sisters-inlaw marrying into the village, nor their children, have been allocated land. Under the "farmland to forest" program (tuigenghuanlin), $11 \mathrm{mu}$ of the family's poorer mountain land was taken for tree-planting about 9 years ago. 
wheat harvest, Li was spending three or four hours each morning cutting grass for the animals, and another five hours hoeing the potato fields in the afternoon. In between, in the middle of the day, she picked up her elder son from school, cooked lunch, did some cleaning and took her son back to school. On the way back, she dropped by at her parents' place to chat with her mother for half an hour or so. Her parents live in the same village, but in a different work team (xiaozu 小组).

Li would like to spend more time with her parents and help her father in the fields. He is in his sixties, but farms $10 \mathrm{mu}$ by himself. Her mother's health is not up to working in the fields, her younger sister has married out, her younger brother is at university and her older brother works as a casual laborer away from home all year round. Li does not have time to help her father, however. In any case, she says, her father-in-law would not allow her to work for her natal family. Li does not even help her parents with the wheat harvest, though this is very common in other families. However, Li's maternal uncles, who live in the same village as her parents, often help her father with the harvest. When it comes time to do the plowing and planting, Li's father hires someone with a tractor to help him.

In Li's marital household, Wang and his father control the finances. Wang brings home his earnings and gives Li a portion in cash, which she keeps at home and uses to cover the children's expenses and to pay for daily necessities. Wang's father is the main decision-maker about farming, for example about how much fertilizer to apply and how many potatoes to sell, while Wang makes decisions about borrowing and repaying money, which they do frequently.

On our second visit, Li confided that there was a great deal of conflict between herself and her father-in-law. He was a domineering man, she said, whose temper had become particularly bad after his eldest son's death. A couple of months earlier, her father-in-law had yelled at her and hit her because he said that she'd been lazy. When $\mathrm{Li}$ told her parents about the violence, her father went to the village government to complain, but the village cadres did nothing: they did not want to get involved in a family conflict.

At the time of this episode, Li and Wang had not yet divided (fenjia 分家) from Wang's parents, but still formed one household - that is, Wang, Li and her sons shared a budget with Wang's parents, and Li cooked for her parents-in-law as well as for her sons and her husband when he was at home, and they ate their meals together. However, when her husband came home for the Spring Festival, she told him about his father's violence, and insisted that they divide the family. Wang was ashamed to divide the family for such a reason; they argued, and he hit her. When we talked with her six weeks later, her arm was still bruised and swollen. If it wasn't for her sons, she said in tears, she would run away, but for now all she could do was wait until her sons were old enough to protect her from her husband.

Li did succeed in dividing the family, at least partially. Wang continued to support his parents financially, giving them cash from his wage earnings, as well as providing them with grain in return for the land that the older man had passed down to his son. However, when we visited in January 2011, Li and her sons were no longer eating their meals with her parents-in-law, and she and her father-in-law 
refused to speak to each other. Li's father-in-law said that it was better this way, because the two generations had different lifestyles.

Shortly after our visit, though, Li and her husband had another violent argument, and Li left. Wang looked for her everywhere in the village and even went to Guyuan, but could not track her down. Two months later, she had not returned. Wang and his father believe that Li has gone out to work as a migrant, and that her natal family know where she is, but they're not telling.

\section{Discussion}

Li's case points to three interrelated aspects of householding as being crucial in shaping patterns of migration in rural China, and their consequences for women's well-being. First of all, householding is a fluid process, incorporating a mix of different strategies employed at different times. Migration is just one strategy, albeit a very important one. It is important to stress also that householding is not just a matter of maintaining livelihoods, but also of caring for dependants, sustaining household members' health and well-being, and maintaining the patriline.

Across rural China, most householding involves a division of labor between wage work (undertaken primarily by men and young single women) and agriculture (undertaken mainly for personal consumption), and the care of dependants, most of which is done by middle-aged and elderly women. According to the China National Rural Survey conducted in 2000, 79 per cent of rural households had at least one person working off the farm. However, very few of these households engaged only in non-agricultural work: 94 per cent still had at least one person doing farmwork. ${ }^{24}$

In Snow Valley, farming is very labor-intensive but not very productive. Villagers have access to relatively large amounts of land, ${ }^{25}$ but much of it is fragmented into plots too small to use tractors, and many are located high up on mountain slopes or terraces. Poor soil quality, lack of rain and the steeply rising costs of inputs, especially fertilizer, mean that the vast majority of villagers can grow only just enough grain for their family to eat, and sometimes not even that. In addition, low agricultural prices mean that the cash income that can be generated from selling produce such as potatoes helps to pay off family debts, but otherwise goes no further than covering basic daily expenditure on things like matches and salt. Households that rely solely or primarily on the meager income to be earned from agriculture commonly skimp on chemical fertilizer and on coal for heating their houses in the harsh Ningxia winter, and subsist on a diet mainly of noodles, with very little meat or vegetables.

24 Bernard H. Sonntag, Jikun Huang, Scott Rozelle and John H. Skerritt, China's Agricultural and Rural Development in the Early 21st Century, ACIAR Monograph No. 116 (2005), p. 243, available at: http://aciar.gov.au/files/node/642/MN116\%20Part\%201.pdf, accessed 8 April 2011. See also Jan Douwe van der Ploeg and Ye Jingzhong, "Multiple Job Holding in Rural Villages and the Chinese Road to Development", p. 519.

25 Across the villages that we visited, the average amount of land per capita ranged between about 2 and $4 m u$ (interviews with village leaders, July 2010). In addition, most households had several $m u$ of sloping land taken over for tree-planting under the "farmland to forest" program (see above, n. 23). 
In addition, there are four major expenses that villagers consider vital for social reproduction, but which they cannot meet through farming alone. These are the bride price that a family must pay in order to obtain a wife for their son, house-building costs, children's education and hospital costs. ${ }^{26}$ To cover these expenses, the vast majority of villagers take out loans from the credit co-op and borrow money from relatives, and then pay back with income earned from wage labor. According to the village head, in Red Mountain the total amount of money that villagers borrow amounts to $700,000-800,000$ yuan, or an average of about 2,200 yuan per household per year.

In order to pay off these debts, households must have at least one person in wage labor, but employment opportunities in this area are few and poorly paid. There are some construction and roadwork jobs in Snow Valley county town and in Guyuan, but wages are low and the costs of commuting high. Like Wang's younger brother and Li's older brother, most migrants travel further in search of higher wages, and live away from home for several months at a time. They return home no more than once or twice a year, because the costs of doing so are too high. In Snow Valley, 76 per cent of the left-behind women who were surveyed (aged 21-50) said that their husbands were away from home for more than nine months in the preceding year. ${ }^{27}$

The nature of the strategies adopted to balance migrant labor and agriculture, and the degree to which those strategies succeed in sustaining the family while keeping workloads bearable, are shaped to a large extent by the availability of labor power and the life-cycle of the household. In most cases, the family planning policy allows couples a second child only if the first is a daughter. However, in Snow Valley single children are rare: most women have two or three children, regardless of whether their firstborn was a boy or a girl. ${ }^{28}$ Boys, in particular, are seen as vital for the labor power that they provide when they grow up, but while they are young they are a heavy burden. This is reflected in Table 2 above, which shows that workloads were heaviest

26 Since the mid-2000s, rural households have no longer had to pay tuition fees for their children's nine years of compulsory education. This has raised social expectations. Whereas previously most Snow Valley villagers expected their children to leave school before the end of junior high school, now they strive for them to go to senior high school and even university. However, the costs of keeping children in school for this long remain extremely high. At the senior high school in Snow Valley county town, tuition fees alone were 1,360 yuan per annum in 2010. With regard to medical expenses, most villagers in Snow Valley are signed up to collective medical insurance, at a cost of 30 yuan per person per annum. However, the insurance only covers 80 per cent of hospital costs. Thus, serious illness or injury continues to be a major financial burden for villagers.

27 In comparison, a survey conducted in five western provinces in 2007 found that an average of 67.5 per cent of left-behind women respondents had husbands who were away from home for nine or more months each year (Ye Jingzhong and Wu Huifang, Qianmo duwu: Zhongguo nongcun liushou funü (Dancing Solo: Women Left Behind in Rural China) (Beijing: Shehui Kexue Wenxian Chubanshe, 2008), p. 71.

28 Among women whom we surveyed in Snow Valley in the age cohort 21-35 years, the mean number of children was 1.7 . In the cohort $36-50$ years, the mean was 2.5 children, and in the cohort 51-60 years, it was 3.2. 
among survey respondents aged 21-35, that is, those most likely to have young children. Interviewees also unanimously pointed to households with young children when we asked who the poorest people in each village were.

Compared with other households with young children, Li and Wang were managing reasonably well financially. Still, the high ratio of dependants to workers in the household meant that $\mathrm{Li}$, being the main carer, had a heavy workload. If or when she returns to her marital household, her work pattern will shift over the next few years because, while her children will require less care, the cost of their schooling will increase, as will her parents-in-law's medical costs. In order to cover these costs, and now that the youngest son is three years old and no longer requires so much attention, her husband is planning to spend more time working in Guyuan, so Li will have to do more of the farmwork on her own.

Existing survey-based studies of left-behind women are built on the assumption that migration is a single event and that there is a sharp dichotomy between "migrants", "left-behind" women and those with non-migrant husbands. As Li's story illustrates, however, migration is often not a single event in the history of a family, and it is undertaken by a range of household members for varying lengths of time. This may help to explain why it is that the variations in well-being among left-behind women and among those with non-migrant husbands (as indicated by the standard deviations in Tables 1-4) are as great as the differences between the two groups.

Most existing studies do not distinguish between left-behind women who have had no previous experience of migration themselves and those like Li who have had such experience. Yet increasing numbers of left-behind women were once migrants. This has both positive and negative implications for these women's well-being. For example, the fact that both $\mathrm{Li}$ and her husband were previously migrants means that they were able to earn a relatively high household income and pay off Li's bride price, which in turn may have reduced stress and anxiety in the family.

On the other hand, Li's previous history of migrant work exacerbated conflict between herself and her father-in-law. Having spent so much time in non-agricultural employment, Li, like most returned migrant women, was relatively inexperienced in farmwork. Comments from both her parents-in-law indicated that she was not very good at it, and this was a source of considerable frustration for them.

In addition, her father-in-law claimed that the family is better off divided because he and his wife have a different lifestyle from that of his son and daughter-in-law. This is an allusion to the fact that living in a town and working as non-agricultural wage laborers has engendered new values and expectations in the younger generation, which clash with those of the older folk. Intergenerational conflict, exacerbated by younger family members' migration and exposure to urban culture, is common in Snow Valley, as elsewhere, and is often expressed more directly than in Li's household. For example, an older woman, Yang, whose relations with her left-behind daughter-in-law were highly conflictual, lamented that the younger woman's previous experiences of working in a city had led her to look down on her husband's rural family and their circumstances. According to Yang, her daughter-in-law refused to eat with her, saying 
she was dirty, and complained bitterly about the run-down state of the house in which they lived. (I will return to the example of Yang and her daughter-in-law later.)

A second characteristic of householding in rural Snow Valley is that it depends on sharing and cooperation. Intra-household divisions of labor, mutual aid with kin and non-kin, and the hiring of labor for farmwork, especially during the busiest agricultural periods, are particularly crucial to householding efforts and to the wellbeing of left-behind women. Many migrants return to the village in July to help harvest the wheat, and households also rely heavily on mutual aid with other kin to get the harvest in. Most married couples live in the same hamlet or village as the husband's brothers and paternal kin, and the wife's parents and other relatives most commonly live in a neighboring village. Couples commonly share harvesting work with relatives on both the man's and the woman's side of the family. Everyone spends a day or two harvesting whichever household's wheat ripens first, and then they move on to the next household. Once the wheat has been harvested, most men leave the village and take up jobs as casual wage laborers.

Left-behind women are not passive in the face of the loss of labor caused by their husbands' departure: like Li, most young women rely heavily on their mother-in-law to help with childcare, domestic work and the care of animals, while they work in the fields. In addition, after the harvest, women and their parents-in-law commonly work together with their neighbors to thresh and grind the wheat. At other times of the year, mutual aid with relatives or other villagers is less frequent, but left-behind women and the elderly commonly hire labor to help with the work of plowing and planting, and less often with the harvesting of linseed and potatoes. These practices of sharing and hiring labor are another factor which helps to explain why rural women's workloads, levels of stress and other aspects of their well-being do not appear to worsen significantly when their husbands work away from home. ${ }^{29}$

Women in Snow Valley also rely heavily on kin, including members of their natal family as well as their husbands' relatives, for financial, material and emotional support. For example, a great deal of borrowing occurs between relatives on both sides of the family - whoever has the money, as villagers explained it. It is also common for young women to make frequent visits to the natal family in the way that $\mathrm{Li}$ does. ${ }^{30}$

For older women, too, connections with adult children are often critically important to their well-being. Women invest considerable effort in cultivating relations with their sons and supporting them materially and emotionally, in the hope and expectation that their sons will support them as they grow older. They also hope that their sons will side with them in family conflicts, including with the sons' wives, and sometimes, as Li hoped, will protect them from the children's father. ${ }^{31}$

29 For further discussion of the importance to left-behind women of mutual aid and other forms of social support, see Ye Jingzhong and Wu Huifang, Qianmo duwu, pp. 390-99.

$30 \mathrm{Li}$ is unusual in visiting her parents every day; other women visit their natal family on a weekly or monthly basis, but stay longer on each visit.

31 Cf. Margery Wolf, Women and the Family in Rural Taiwan (Stanford: Stanford University Press, 1972). 
With virilocal marriage - by far the most common form of marriage across rural China-daughters, once married, are expected to shift the bulk of their allegiance and support to their marital household. However, in practice in Snow Valley, married-out daughters, as well as sons, provide material support to their parents, including their own and their husbands' labor at harvest time, and money, food and clothing. In addition, for most women, the emotional support that adult daughters and also sisters provide, through telephone calls as well as visits home, is at least as important as that provided by sons. For example, in another instance of domestic violence that we encountered, this time of an older woman named Xie, who was beaten frequently and very violently by her husband, it was Xie's adult daughters who did most to try to reason with their father and stop him from hitting their mother, and to try to persuade the village cadres to intervene.

Large-scale migration has provided both opportunities and difficulties for women trying to maintain and cultivate connections with their natal families. On the one hand, migrant work enables women to provide more financial and material support to their parents than was previously possible. ${ }^{32}$ On the other hand, migrant work is also contributing to an attenuation of ties between women and their natal families. Most of our Snow Valley respondents had been introduced to their husbands by relatives or a matchmaker organized by their parents, and most married into villages near that of their parents. However, a small but increasing number of young women are now marrying out to distant counties and provinces, with men whom they have met while working as migrants away from home. Others are marrying locally but, like $\mathrm{Li}$ and her sisters-in-law, are moving with their husbands to distant locations in search of work. In settling long distances away from home, these women reduce their ability either to provide support to their mother or to receive it from her. ${ }^{33}$

In addition to being marked by cooperation, householding and its consequences for women's well-being are shaped by intra-family power relations and inequalities, and by divisions and conflict within families. The main axes of conflict are between women and their husbands and between women and their parents-in-law. In the latter type of conflict, husbands often try to act as mediators. However, in Snow Valley we found that husbands most commonly sided with their parents. This was certainly the case in Li's family, and also in Yang's. This might explain our survey finding that

32 Aside from this, Weiguo Zhang claims that, in North China, women's contacts with their natal families have increased in the post-Mao era for various reasons, including the greater degree of freedom that individuals have gained in managing their own time as a result of decollectivization and the greater ease of communication and mobility that has come with road-building, improvements in transport, and communications technology (Weiguo Zhang, "“A Married Out Daughter is Like Spilt Water'?: Women's Increasing Contacts and Enhanced Ties with their Natal Families in Post-Reform Rural North China", Modern China, Vol. 35 [2009], pp. 256-83).

33 For further discussion of the relationship between rural migration, marriage strategies and women's kinship ties, see Shannon May, "Bridging Divides and Breaking Homes"; Ellen R. Judd, "Family Strategies". 
young, left-behind women are less likely to report conflict with other family members than are young women whose husbands are at home most of the year.

In Li's marital household, power relations were dominated to an unusual degree by her father-in-law and his interests. Other men of his age had ceded most decisionmaking power to their sons, and, alongside a major reduction in the work that they contributed, their authority declined relative to their sons, daughters-in-law and even their wives, who tended to be more actively involved in householding. In most cases, the situation was more like it was in Yang's household, where Yang's husband was so marginal to both decision-making and household work that he was scarcely mentioned by either Yang or her daughter-in-law. In this household, as in the majority, the greatest generational conflict was between the older woman and her daughter-in-law.

Across rural China, the authority and decision-making power of young married women has increased in recent decades relative to their parents-in-law, ${ }^{34}$ but relative to their husbands it has increased less. Male outmigration has had little effect on this. A few left-behind women said that, in their husband's absence, they took responsibility for key decisions, such as what crops to plant and how much to sell, and, in one case, whether or not they should pay for a teenage daughter to continue her schooling or send her off to work. They experienced that responsibility as stressful, and as a burden rather than as an increase in their power. In any case, most women with migrant husbands said that financial decisions were made by either their husband or in consultation with their husband on the telephone or on his visits home. According to villagers, the reason for this is that men in most households in Snow Valley are the wage earners, while women do not earn cash incomes. As villagers put it, "he earns the money, so he decides [how it's spent]".

Not everyone agreed. In Yang's household, Yang and her daughter-in-law had more personal authority and played a greater role in decision-making than either Yang's husband or her son. When Yang's son came home for the Spring Festival, he handed over his earnings to his wife, who then decided how much of it should go toward debt repayment, how much she would give to her parents-in-law, and how much she would keep for herself and her small child. Most other decisions, about farm inputs and the distribution of labor, were made by either Yang or her daughter-in-law, or were the result of fraught negotiations between the two.

In the literature, left-behind women are most commonly portrayed as a helpless, passive "vulnerable group" (ruoshi qunti 弱势群体). Women like Yang and her daughter-in-law give the lie to that image. Even the strongest women are severely constrained by powerful gender discourses, institutions and practices, however. These include village officials' tendency to refuse to intervene in cases of even the most extreme domestic violence. They also include gender divisions of labor and norms about women's work and men's work that disadvantage women. Thus, women are expected to take responsibility for unpaid childcare and

34 Ellen R. Judd, Gender and Power in Rural North China (Stanford: Stanford University Press, 1994), pp. 189-91. 
domestic work, which, however, is not appreciated as hard work, and does not earn women respect or authority in the family.

Women's lack of power is further reinforced by the fact that financial transactions with external bodies are undertaken with the head of the household, who is almost always a man. All but one of the married women whom we interviewed said that their household's bank loans were in their husband's or adult son's name. Government payments for land taken for reforestation are also paid to the household head. Last, but by no means least, land use rights in Snow Valley are almost always contracted to the male head of the household, and practices relating to land redistribution and inheritance are shaped in the interests of the patrilineal family. Thus, parents commonly pass their land down to their sons, but not to their daughters. ${ }^{35}$ When a woman divorces, she must leave her husband's household and, wherever she ends up living, neither her natal village nor her husband's village will allocate her land. ${ }^{36}$

Women's limited land usage rights and lack of financial autonomy can have severe consequences for their well-being. Xie, for example, cannot visit the doctor to have her injuries from her husbands' bashings seen to, because her husband refuses to pay for such a visit, and she cannot pay herself. While her husband has agreed to the divorce that Xie requested, she feels she cannot go through with it because neither her brothers nor any other family members will take her in and support her if she divorces. Without any land of her own to farm, she literally has nowhere to go.

Rachel Murphy argues that women who themselves have been migrants can use this work experience as a "fallback position". ${ }^{37}$ In other words, the bargaining power of such women in the household is strengthened by the fact that they can threaten to leave and go back to migrant work, should their well-being in the household be threatened. However, this does not provide much of a fallback for older women like Xie. Even if she had previously worked as a wage laborer, now that she is in her 50s and suffers from rheumatism, not to mention that her health is damaged by years of beatings, her chances of finding waged work that will enable her to survive on her own are slim.

For Li, migrant work may provide an effective fallback position. Certainly, her husband and in-laws find it extremely difficult to manage the work of householding now that Li has gone, and this may pressure them to be less abusive if she returns. Ultimately, though, as both she and her marital family know, Li's

35 Even daughters without brothers do not necessarily inherit property; they only do so if they have married uxorilocally.

36 There is considerable regional variation in the way in which land usage-rights are distributed but, across rural China, discrimination against women in this regard is common. For further discussion, see Sally Sargeson and Song Yu, "Gender, Citizenship and Agency in Land Development", in Tamara Jacka and Sally Sargeson (eds), Women, Gender and Rural Development in China (Cheltenham: Edward Elgar, 2011), pp. 24-48; Laurel Bossen, "Reproduction and Real Property in Rural China: Three Decades of Development and Discrimination", in Tamara Jacka and Sally Sargeson (eds), Women, Gender and Rural Development in China, pp. 97-123.

37 Rachel Murphy, “The Impact of Labor Migration”, p. 265. 
husband and in-laws still hold the trump cards. Given women's lack of property rights and the high odds against them being able to survive past middle age on migrant wage earnings, the risks of divorce remain extremely high.

\section{Conclusion}

Douglass' concept of householding and his focus on the interconnections between outmigration and householding offer a fruitful analytical framework for understanding circular migration and its impact on the well-being of rural women. One particularly valuable aspect of this approach is the emphasis on householding as "an ongoing, dynamic social process that covers all life-cycle stages". ${ }^{38}$ A second important feature is the understanding that sustaining households involves the reproduction of social relations as well as the physical reproduction of human beings, and the maintenance of the emotional as well as the physical well-being of household members. On the one hand, this aspect of householding studies contrasts with most research into "household strategies", "new economics of labor migration" and "sustainable livelihood strategies". ${ }^{39}$ These latter studies, undertaken primarily by development economists and sociologists, focus on household economic strategies, especially the diversification of the productive activities in which household labor is deployed, and their effect in maintaining livelihoods. However, they generally neglect or downplay the importance that people attach to nurturing emotional bonds with kin both within and outside households, and to caring for and ensuring the health and emotional well-being of household members. ${ }^{40}$ On the other hand, householding studies also differ from anthropologists' and migration experts' studies of "family strategies" and (transnational) family networks. These latter commonly emphasize the social reproduction of families and the pursuit of social security, for example through the pairing up of people in cross-boundary marriages, but tend to downplay the "livelihood strategy" aspect of such links. ${ }^{41}$

38 Mike Douglass, "Global Householding in Pacific Asia", p. 423.

39 See, for example, Frank Ellis, "Household Strategies and Rural Livelihood Diversification", Journal of Development Studies, Vol. 35, No. 1 (1998), pp. 1-38; Flemming Christiansen, "Building Livelihoods: How Chinese Peasants Deal with State Regulation of Opportunity and Risk", in Norman Long, Ye Jingzhong and Wang Yihuan (eds), Rural Transformations and Development-China in Context: The Everyday Lives of Policies and People (Cheltenham: Edward Elgar, 2010), pp. 133-51.

40 For further discussion and critique, see Leo de Haan and Annelies Zoomers, "Exploring the Frontier of Livelihood Research", Development and Change, Vol. 36, No. 1 (2005), pp. 27 47; Heather Xiaoquan Zhang, "Conceptualising the Links: Migration, Health and Sustainable Livelihoods in China", in Heather Xiaoquan Zhang, Bin Wu and Richard Sanders (eds), Marginalisation in China: Perspectives on Transition and Globalisation (Aldershot: Ashgate, 2007), pp. 195-214.

41 See, for example, Deborah Bryceson and Ulla Vuorela (eds), The Transnational Family: New European Frontiers and Global Networks (Oxford: Berg, 2002); Shannon May, "Bridging Divides and Breaking Homes"; Ellen R. Judd, "Family Strategies". 
Another important aspect of Douglass' approach is his description of households and householding as characterized by internal conflict and contestation as well as by cooperation. Indeed, one of the reasons that Douglass refers to the household, rather than to the family, is "to avoid the treatment of family as a black box presumed to have a single utility function with decisions harmoniously made around one decision maker". ${ }^{42}$ The point is well taken, although many studies of migration focusing on the "household" have assumed it also to be a single, homogeneous decision-making entity.

In the rural Chinese context, however, Douglass' discussion of householding as a continual, fluid process or set of processes, shaped through power relations and characterized by varying patterns of contestation and co-operation between kin, is more useful than are his references to the household as an entity. I say this for three reasons. First, Douglass' distinction between "household" and "family" does not accord well with Chinese understandings. "In contrast to 'family",, Douglass writes, "... a household may consist of fictive as well as actual kin, of distant as well as under-the-roof members". ${ }^{43}$ However, in Chinese, the "household" ( $h u$ 户) is primarily an administrative term and refers to kin who share a budget and eat together. Nowadays, rural households include family members who migrate out and eat away from home, but this is usually only so long as the migrant shares a budget with other members of the household. Unrelated people, such as hired laborers, are usually not considered part of a household, even if they live and eat with household members. "Family" (jia 家) is a vaguer but more commonly used term, sometimes coinciding with "household", and sometimes referring to the multiple small households that have been formed as a result of family division (fenjia 分家), a process that generally occurs sometime after an adult son "takes in" a bride and has children. When married women use the term "family", they sometimes also include members of their natal family.

Second, as was made clear in Li's story, one drawback of Douglass' notion of the household is that some of the strategies that he refers to as "householding" are decided upon as a means for sustaining and reproducing the larger family, rather than, or in addition to, sustaining one of the individual households that constitute that family. This includes the very decisions about whether or when to divide the family and set up a new household; this is an integral component both of "householding" and of strategies for reproducing the broader family and patriline. In addition, the contestation which Douglass highlights as being crucial to households and householding is also characteristic of the larger family, and the two forms of contestation are often connected.

Third, within any one objectively defined household or family, individuals may not share the same notion of family, and the goals of their householding strategies might be somewhat different. In particular, as I have shown, married women's householding often incorporates connections with their natal families,

\footnotetext{
42 Mike Douglass, "Global Householding in Pacific Asia”, p. 421, n. 1.

43 Ibid.

44 Ellen R. Judd, Gender and Power in Rural North China, p. 174.
} 
and sometimes these conflict with the householding interests of their husband's family. It may be most useful to conceive of householding as a process shaped by contestation and cooperation between kin-related individuals, who may, however, have quite different understandings as to who - which individuals, households or families-benefit from which householding strategies.

One final weakness in Douglass' concept of householding is an inadequate accounting for the ways in which householding strategies are shaped and constrained by institutions and practices external to the household and family. Like studies of household livelihood strategies and those that focus on transnational family networking, Douglass' approach is in part a reaction against studies of development and migration, which focus on macro structural forces to the neglect of household and individual agency. There is a danger, however, that focus on householding will lead researchers to downplay the constraints resulting from broader social and political institutions.

In the scholarship on China, the significance of the household registration system in constraining migrants and their households is well recognized. ${ }^{45}$ Far less well recognized is the impact of gendered institutions, including domestic violence, gender divisions of labor and gender-discriminatory practices relating to the allocation of funds and property, which the contemporary state condones and reinforces. These gendered institutions play a crucial role in both shaping migration patterns and other aspects of householding and in limiting women's ability to benefit from migration and minimize threats to their well-being.

Although, given the unprofitability of agriculture in so much of inland rural China, rural householding across China is likely to continue to be characterized for the foreseeable future by the kind of mix of farmwork and temporary circular migration that is evident in Snow Valley, there are likely to be increases both in the number of rural outmigrants and in the frequency and duration of migrant episodes. This will increase the number of left-behind women and make it harder for them to maintain their own and their family members' well-being in the face of the difficulties posed by the absence of their husbands and other villagers. These difficulties cannot be overcome through the state's current efforts to create a "new socialist countryside" and ameliorate rural-urban inequalities by raising villager incomes and funding the provision of public goods. Vital as these efforts have been in reducing poor villagers' struggle to meet basic needs, they have little impact on gendered institutions, which undermine women's agency and underpin their subordination and vulnerability to violence in the family.

Nor do local government efforts work with and build on left-behind women's own agency and self-organization. For example, local governments in a few places

45 For accounts of the household registration system, of reforms to the system, and how these have shaped migration patterns, see Kam Wing Chan and Will Buckingham, "Is China Abolishing the Hukou System?", The China Quarterly, No. 195 (September 2008), pp. 582-606, and Cindy Fan, China on the Move. 
have organized mutual aid teams among left-behind women. ${ }^{46}$ These intra-village efforts fail, however, to take account of the significance of the ties that married women maintain with their natal families, who usually live in a different village. As Ellen Judd has suggested, efforts which locate women's kinship in the spaces defined by virilocality "may be misguided, and a different approach to the question of women's place in the countryside may be required - one that moves from an emphasis on community to an emphasis on networks crossing community lines". ${ }^{47}$

The higher incomes obtained by rural households with migrant workers have not translated into improved well-being among the women "left behind" in the countryside. The incorporation of migration into rural householding has, however, minimized the negative effects of outmigration on left-behind women. In the future, this may change, for increases in the frequency and duration of migration episodes will make it harder for left-behind women to meet the challenges posed by the absence of husbands and others. Substantial improvements in the well-being of leftbehind women will only occur when measures are introduced to overcome gendered, institutional constraints on women's agency in householding, and to build upon rather than ignore or sideline the critical householding resources which leftbehind women themselves generate through cooperation and networking.

46 Wang Daxian, "Nongcun 'liushou funü' huzhu hezuo wenti de diaocha yanjiu: yi Anhui sheng Hanshan xian wei li" (Survey Research on Mutual Aid and Cooperation Among Rural "Left-behind" Women: Examples from Hanshan County, Anhui Province), Anhui ligong daxue xuebao (shehui kexue ban) (Journal of Anhui University of Science and Technology [Social Science]), Vol. 12, No. 3 (2010), pp. 81-104; "Chungeng nongmang, Meishan liushou funü baotuan huzhu" (During the Spring Plowing Busy Season, The Leftbehind Women of Meishan Band Together in Mutual Aid), Zhongguo funü bao (China Women's Daily), 6 April 2010; "Huzhuzu rang liushou funü zou shang shengchan shenghuo xin lu" (Mutual Aid Groups Enable Left-behind Women to Walk a New Path in Production and Life), Zhongguo funü bao, 20 August 2009.

47 Ellen R. Judd, "Women on the Move: Women's Kinship, Residence, and Networks in Rural Shandong", in Bryna Goodman and Wendy Larson (eds), Gender in Motion: Divisions of Labor and Cultural Change in Late Imperial and Modern China (Lanham: Rowman and Littlefield, 2005), p. 113. 